MÁRTON VARJU ${ }^{*}$

\title{
The Right to Effective Judicial Protection in the System of Judicial Review in the European Community
}

\begin{abstract}
The system of judicial review in the European Community has recently come under scrutiny on grounds of the right to effective judicial protection as provided in Article 6 ECHR and in the Charter of Fundamental Rights of the European Union. The applicants in cases UPA and Jégo-Quéré claimed that in case their action was found inadmissible under Article 230 (4) $\mathrm{EC}$, they would be deprived of effective judicial protection since other means of protection against violation of law by the Community do not provide adequate remedies. The Court of First Instance in Jégo-Quéré responded to the claims of the applicant by concluding that a new interpretation of the condition of individual concern laid down under Article 230 (4) EC could ensure the right to effective judicial protection in the system of judicial review in Community law. In spite of the fact that the Advocate General also envisaged that the amendment of the condition of individual concern may guarantee the protection of this right, the Court of Justice in UPA rejected such a solution, and stated that it is the duty of the Member States to provide effective judicial protection under Community law acting on national or Community level.
\end{abstract}

Keywords: European Community law, preliminary ruling procedure, action for annulment, right to effective judicial protection, European Court of Justice

\section{Introduction}

Criminal Two recent cases ${ }^{1}$ have shed further light on the understanding of the European Courts as regards to the admissibility of actions for annulment under Article 230 (4) EC. The Treaty and the right to effective judicial protection have always been in conflict, and the European Courts had to do their best in order to ensure that both are respected. In the analysed cases the European Courts brought judgements, which evaluated the problem in different ways. The European Court of Justice (Court) tackled the question of enforcing the right to effective judicial protection under Article 230 (4) EC actions by examining whether it could depart from the wording of the

\footnotetext{
* Assistant lecturer, University of Debrecen, Department of European Law, Debrecen. E-mail: pocbog@yahoo.co.uk

${ }^{1}$ Union de Pequenos Agricultores v. Council T-173/98 [1999] ECR II-3357 and C50/00 P [2002] ECR I-6677, Jégo-Quéré et Cie SA v. Commission T-177/01 [2002] ECR II-2365.
} 
Article in question in order to ensure effective judicial protection. The Court of First Instance (CFI) followed another line of argument concentrating on a possible change in judicial attitude towards the notion of individual concern in order to establish effective judicial protection. The clear contradiction in case law is shadowed, however, by the latter decisions of the CFI, in which it followed the position of the Court. Nevertheless, it has been shown that other solutions can be admissible in case law.

Under the rule of law, Community law must establish a system of review of Community measures. The subjects-at-law are entitled to initiate an action for annulment of a Community measure, which invests rights or imposes obligations on them. During the action for annulment the validity of a Community measure is under scrutiny on the following grounds: lack of competence, infringement of an essential procedural requirement, infringement of the Treaty or of any rule of law relating to its application, misuse of powers.

Article $230 \mathrm{EC}$ on the action for annulment distinguishes among the subjectsat-law of Community law on the basis of the scope of their right to initiate an action for review. Privileged applicants, such as the Member States, the Council, the Commission, and for the purpose of protecting their prerogatives, the European Parliament, the Court of Auditors and the European Central Bank are entitled to bring an action for annulment of regulations, decisions, directives, and the regulations, decisions concerning the European Central Bank in the European Court of Justice. The acts of the European Parliament can be brought under review, if they are intended to produce legal effects vis-à-vis third parties. In the application for annulment brought by privileged applicants, the Treaty does not require the proof of existence of conditions of admissibility, contrary to the applications lodged by non-privileged applicants, i.e. natural or legal persons.

If natural or legal persons wish to attain the direct review of a Community measure under Article 230 (4) EC, they must provide proof of the existence of serious conditions of admissibility. The Treaty contains three conditions of admissibility. Firstly, the nature of the Community measure under scrutiny; secondly, the individual concern, and finally, the direct concern. Regarding the point of view of the cases analysed below, only the first two conditions are significant, rendering the examination of the third condition negligible in this case. The Treaty allows non-privileged applicants to bring an action for annulment of a Community measure, if the measure is: a decision addressed to the applicant; a decision addressed to another party, but the applicant is of individual and direct concern to the measure; and, a decision in the form of a regulation when the applicant is of individual and direct concern to the 
measure. It is evident from the rules mentioned above, that non-privileged applicants can ask for the review of a measure of specific application addressed to them without proving the existence of the other conditions of admissibility. The Treaty, however, requires the proof of other conditions of admissibility if the applicant asks for the review of a Community measure of specific application not addressed to the applicant, or if the Community measure in form is of general application, but in substance is of specific application. It can be concluded that the Treaty offers the right to initiate an action for annulment of a Community measure for non-privileged applicants in case the measure is a decision and is addressed to the applicant, or the applicant is of individual and direct concern to the decision. ${ }^{2}$

In the case law of the European Court of Justice the examination of whether the measure under review was a regulation or a decision, and whether the applicant was of individual and direct concern to the measure has been separated for a long time. The question of "regulation-decision" was decided under Article 249 EC on the basis of being of general or of specific application. If the Court thought that the measure under review qualified as a regulation, it could declare the action inadmissible without examining whether the applicant was of individual and direct concern to the measure. It appeared in case law, however, that the applicant was of individual concern to some valid regulations, therefore the necessity of the application of the "regulation-decision" test was questioned. The Court in Codorniu ${ }^{3}$ stated that a Community measure of general application may be brought under review by a non-privileged applicant, if the applicant was of individual concern to the measure. Since Codorniu, individual concern has been the thoroughly examined condition of admissibility. The Court defined the notion of individual concern in the Plaumann case. ${ }^{4}$ According to the Court, natural or legal persons shall be regarded as individually concerned by a measure not addressed to them, if it affects their position by reason of certain attributes peculiar to them, or by reason of circumstances which differentiate them from all other persons, and distinguishes them individually in the same way as the addressee. This means that the applicant must be distinguishable from all others by reason of some of his peculiarities, or by reason of a factual situation. It can be asserted that both the European Court of Justice and the Court of First Instance have applied the Plaumann-test rather strictly. The

2 See also: Hartley, T. C.: The Foundations of European Community Law. $4^{\text {th }}$ ed. Oxford, 1998. 327-376.

3 Codorniu SA v. Council C-309/89 [1994] ECR I-1853.

4 Plaumann \& Co. v. Commission C-25/62 [1963] ECR 95, 107. 
European Courts interpreted individual concern in such way that very few actions by natural or legal persons have been found admissible on this basis. ${ }^{5}$

If the European Courts reject the application for annulment on grounds of inadmissibility, the only other way of the review of Community law is through the preliminary ruling procedure. ${ }^{6}$ In this procedure the national judge asks the Court in the form of judicial questions to decide on the validity of the Community measure applied in the proceedings in the national court. This procedure, however, does not guarantee access to the European Court of Justice. The preliminary ruling procedure requires a procedure in a national court, and the posing of a question on validity by the national judge, because the assertion [by the party] of the invalidity of the measure does not bind the national judge to turn to the European Court of Justice. The preliminary ruling procedure, in our view, is not an adequate alternative for Article 230 EC action.

Article 235 EC and Article 288 (2) EC jointly establish a Community remedy for individuals against Community violations of law. These dispositions rule on the procedure of non-contractual liability of the Community. This procedure, nevertheless, is not aimed at the annulment of the Community measure, rather, it focuses on the compensation for damages. It can be concluded from the facts mentioned above, that the Treaty does not provide complete and effective judicial protection for individuals who have rights and obligations derived from the Treaty against unlawful Community measures. Since the European Community is based on the rule of law, it must ensure that the right to effective judicial protection is enforced. This obligation of the Community was recalled under the Union de Pequenos Agricultores, ${ }^{8}$ and subsequently the European Courts were asked to revise their standpoint concerning the admissibility of Article 230 EC action.

The argument above is supported by precedents. In ASOCARNE, ${ }^{9}$ the applicant referred to the disadvantages of the review via the preliminary ruling procedure, being fully aware of the delay factors in the functioning of the

5 See also: Neuwahl, N.: Article 173 Paragraph 4 EC: Past, Present and Possible Future, 199621 EL Rev. 17-31.; Ward, A.: Amsterdam and Amendment to Article 230 EC: an opportunity lost or simply deferred? In.: The Future of the Judicial System of the European Union (ed.: Dashwood, A.-Johnston, A.), 2001. Oxford and Portland, Oregon. 37-40.

${ }^{6}$ Article 234 EC.

7 See also: Ward, A.: Judicial Review and the Rights of Private Parties in EC Law, 2000. Oxford, 202-287.; Arnull, A.: The European Union and its Court of Justice. Oxford, 1999. 21-69.

8 Jégo-Quéré et Cie SA v. Commission..., op. cit. par. 28.

9 ASOCARNE v. Council C-10/95 P [1994] ECR II-871. 
Spanish judicature, in order to establish the admissibility of action. The Court, however, decided that it can only proceed within the framework of the Treaty and shall not depart from the conditions of admissibility as set forth under the Treaty on the basis that the other judicial channel of review does not provide adequate judicial protection. The Court of First Instance in Salamander ${ }^{10}$ rejected the argument in which the applicant stated that in case of rejection of its application, it would not receive effective judicial protection in the national court, because the preliminary ruling procedure is less effective than the procedure under Article 230 EC. The court argued that even in case of ineffective judicial protection, it cannot amend the Treaty in order to change the system of remedies. The features of Article $234 \mathrm{EC}$ action do not establish the admissibility of application under Article 230 EC action. In Pescadores ${ }^{11}$ the Court repeated this standpoint, in spite of the fact that the applicant relied on Article 6 of the European Convention for the Protection of Human Rights and Fundamental Freedoms (ECHR) on adequate court procedures. The standing of the case law shows that by applying such arguments one cannot efficiently rely on the right to effective judicial protection in order to declare an action admissible. The question is whether there is another line of argument serving as a basis for the European Courts to accept the reference to the right to effective judicial protection in annulment cases? In the case examined, first the applicant, then the Advocate General tried to convince the European Courts that effective judicial protection is not completely accomplished in the Community.

\section{Reaffirming judicial attitude towards annulment actions: the $U P A$ case}

The application for annulment of Regulation $1638 / 98 / \mathrm{EC}^{12}$ by the Union de Pequenos Agricultores was lodged at the Registry of the Court of First Instance on 20 October 1998. The Regulation in question amended Regulation $136 / 66 / \mathrm{EEC}^{13}$ on the establishment of a common organisation of the market in

${ }^{10}$ Salamander AG and Others v. Parliament and Council T-172/98, 175-177/98 [2000] ECR II-2487.

${ }^{11}$ Federacion de Cofraidas de Pescadores de Guipuzcoa and Others v. Council C300/00 P(R) [2000] ECR I-8797, par. 84.

${ }^{12}$ Council Regulation (EC) No. 1638/98 of 20 July 1998 amending Regulation No. $136 / 66 / \mathrm{EEC}$ on the establishment of a common organisation of the market in oils and fats, OJ L 210, 28/07/1998. 32-37.

${ }^{13}$ Regulation No. 136/66/EEC of the Council of 22 September 1966 on the establishment of a common organisation of the market in oils and fats, OJ, English Special Edition 1965-1966, 221. 
oils and fats, in particular the common organisation of markets in olive oil. Fundamentally, the Regulation amended the subvention system of olive oil production. The applicant is a trade association, who represents and acts in the interests of small Spanish agricultural businesses and is considered a legal personality under Spanish law. The Council raised an objection of inadmissibility on 23 December 1998. The CFI upheld the objection of inadmissibility and dismissed the application as inadmissible.

According to settled case law, the CFI examined the nature of the challenged provision and decided that it was of general application and was legislative in character that it did not substantiate a decision according to Article 249 EC. Pursuant to settled case law, the court went on to examine whether the contested measure of general application may be of individual concern to the applicant that it affects the applicant in a way that he can be differentiated from others either by reason of certain attributes which are peculiar to them or by reason of circumstances. The CFI pointed out that applications from associations were found admissible, when the challenged Community act guaranteed procedural powers to them, or they represented undertakings, which would [themselves] be entitled to bring actions, or when the contested measure affects their interests as associations. ${ }^{14}$

When applying the criteria mentioned above, the CFI decided that the applicant had not proved that its members could be differentiated from others by reason of certain attributes, which are peculiar to them or by reason of circumstances. It argued that in spite of the fact that some members of the applicant operated in the given market and that some of them were forced to give up operation in the market, they could not be differentiated from others because their market position is comparable on objective grounds with the market position of others even in the present, or in the future. In addition, the CFI concluded that the applicant could not prove the existence of any specific interest that would imply he was individually concerned. Furthermore, it stated that the applicant could not prove the admissibility of his actions under the case law concerning associations.

The last argument of the applicant focused on the fact that a denial of admissibility under Article 230 EC would deprive him from effective judicial protection. In his view, there was no legal mechanism in the applicable national law that would guarantee the review of Community law via preliminary ruling. The CFI declined the argument stating that according to the principle of equality, the success of review of Community law must not depend on the different conditions stipulated by applicable national law. According to the

${ }^{14}$ Union de Pequenos Agricultores v. Council... op. cit. par. 45. 
principle of sincere co-operation as laid down under Article $10 \mathrm{EC}$, the Member States must establish a complete system of remedies in order to ensure the review of Community law. On these grounds it is not exclusively the court's task to guarantee the right to effective judicial protection, but it is the obligation of the Member States. The CFI may not depart from the law to guarantee this right. The argument of the applicant that the preliminary ruling proceedings would last long under effective rules must not substantiate an exemption from the requirements as pursuant to Article 230 (4) EC.

In its appeal the UPA presented the following arguments. He stated that when the CFI declared the application inadmissible, it violated UPA's right to effective judicial protection guaranteed by Community law. According to the appellant, Community law did not provide an alternative remedy to the one prescribed under Article $230 \mathrm{EC}$, because in the given case the procedure for preliminary ruling was excluded. Firstly, there was no related national regulation, secondly, it was not possible to infringe the provisions of the Regulations by virtue of their content that the appellant could institute proceedings. The appellant concluded that the CFI must examine in each case whether another remedy was at disposal.

The Council and the Commission in their intervention rejected the arguments of the applicant. According to their views, the conditions for actions for annulment were set forth under Article 230 (4) EC, in which the right to effective judicial protection was not included. They pointed out that the appeal was not aimed at the substantial part of the judgement, in particular at individual concern, but it replied to the content of the judgement in the light of effective judicial protection. The Council and the Commission stated that the Treaty had established a complete system of remedies. When the Member States entailed difficulties in the functioning of the system by obstructing the course of preliminary ruling proceedings, they violated their obligation of sincere co-operation laid down under Article 10 EC. Pursuant to this, the proceedings under Article 226 EC shall be instituted against the Member State.

The Commission rejected the criticism of the improper functioning of the system of remedies as pursuant to the Treaty in the following way. When an application is lodged, the relevant national authorities must commence proceedings under a directly applicable regulation. If the national authority does not commence proceedings in due course or its decision is contrary to the interests of the citizen, the national judicial remedies will be at disposal and then it is possible to rely on the preliminary ruling procedure.

The Court affirmed the conclusions of the Court of First Instance with respect to case law concerning Article 230 (4) EC and it recorded the wellknown conditions of action for annulment by non-privileged applicants. After 
concluding that the appeal basically focused on the guarantee of the right of effective judicial protection, the Court went on as follows. Whence, the European Community is based on the rule of law, it shall ensure that the law created by its institutions is reviewed. Pursuant to this, individuals are entitled to effective judicial protection of their rights guaranteed by Community law. This entitlement stems from the common constitutional traditions of the Member States and is protected by the European Convention on Human Rights. The Treaty of Rome has established the complete system of review under Community law, which functions via European court actions and national court remedies. Inasmuch as the Community has fulfilled this obligation laid down in the Treaty, it is the obligation of the Member States to supplement the system of effective judicial protection. The courts in the Member States must interpret the rules of national law in such a way that the review of Community law is possible. Furthermore, it is neither the duty, nor the competence of the European Courts to examine the national rules of procedure or national substantial law when they decide on admissibility or to decide whether direct action under Article $230 \mathrm{EC}$ is required in order to guarantee the right to effective judicial protection. The European Courts cannot depart from the condition of individual concern in order to declare actions admissible on the grounds of the right of effective judicial protection, because the Treaty requires them to apply it. If the Member States view the system of remedies established by the Treaty inadequate, it is their responsibility to initiate the amendment of the Treaty under Article 48 TEU. ${ }^{15}$ The Court decided that the CFI did not err when it declared the action inadmissible without the examination of whether another remedy existed. Therefore, the Court rejected the appeal.

In its judgement the European Court of Justice had to follow two ways of reasoning, one concerning Article 230 (4) action and one concerning the right to effective judicial protection. If the reasoning on the action for annulment is examined, it can be concluded that the Court followed a well-known path. Its reasoning is consistent and well-grounded, it pinned down [again] the conditions of Article 230 (4) action as prescribed under the Treaty and in case law. The Court's reasoning on individual concern was the usual, it must be proved that the applicant belongs to a closed category by reason of certain attributes peculiar to him or by reason of circumstances in which the applicant can be distinguished from others.

It is noteworthy that the Court of First Instance, besides applying the classical Plaumann-test, decided upon admissibility by examining case law on

\footnotetext{
${ }^{15}$ Treaty on European Union.
} 
the admissibility of applications lodged by associations. This means that the analysis of the European Courts concentrates on finding a common element in the case in front of them and in a previous case, where individual concern was established under Plaumann based on the fact in question. The question of individual concern is decided by comparing specific facts determined in previous cases and not by applying the general concept of individual concern as in Plaumann. This means, that according to case law there is a separate set of conditions established on the grounds of Plaumann concerning the admissibility of applications lodged by associations. ${ }^{16}$ The use of special categories crystallised from the general concept in Plaumann appears not only in this specific area, but in such territories, where the decision on individual concern is based on peculiarities and circumstances returning case-by-case. ${ }^{17}$ This method may facilitate the application of law, however, it may result in a stiffening of the applied law. This may exclude a wider domain of interpretation provided under the general concept of individual concern by not permitting deflection from the specific conditions of admissibility.

Concerning the right to effective judicial protection the Court recognises the right and its obligation to guarantee such right. The sole purpose of its argumentation, however, is to point out the limits of its powers, which exclude the fulfilment of this obligation. Viewing the question from a formal point of view, it can be asserted that the Court shall not overreach the facilities provided by the Treaty. From the Court's point of view, the system of judicial protection is complete, because it may manoeuvre within the limits of the Treaty and the Court takes advantage of its elbow-room. The Member States, however, under Article $10 \mathrm{EC}$ must create such rules of procedures and the national court must interpret and apply these rules in such a way, that the right to effective judicial protection prevails in the Community. Moreover, it is the obligation of the Member States as objects of international law that by the amendment of the Treaty this right is enforced. Consequently, the Court can do nothing else but burden those obligated by law with the obligation to establish a complete and effective system of judicial protection. That is why, the

\footnotetext{
${ }^{16}$ Expressly granted procedural powers, members of which are entitled to bring action for annulment, own interests, Union de Pequenos Agricultores v. Council... op. cit. par. 47.

${ }^{17}$ Obligation to take into consideration (Piraiki-Patraiki and Others $v$. Commission C11/82 [1985] ECR 207; Sofrimport v. Commission C-152/88 [1990] ECR I-2477; Antillean Rice Mills v. Commission T-480/93 and T-483/93 [1995] ECR II-2305), procedural rights (Rica Foods v. Commission T-47/00 [2002] ECR II-113, Sociedade Agricola dos Arinhos and Others v. Commission T-38/99-50/99 [2001] ECR II-585); special situation (Extramet Industrie v. Council C-358/89 [1991] ECR I-2501, Codorniu SA v. Council.. op. cit.).
} 
enforcement of the right to effective judicial protection is in the competencies of the Member States.

The Court pays less attention to the problems concerning the preliminary ruling procedure than the Commission, because the Court understands that the difficulties of the preliminary ruling procedure lay rather in Community law, than in the law of the Member States. Among the dispositions under the Treaty, it is not the provisions concerning the preliminary ruling procedure that impede the effective review of Community law, since the preliminary ruling proceeding is regulated with the intention that it may be initiated when a national judge decides so in a dispute in front of him. Moreover, its objective was to ensure the uniform interpretation and application of Community law by the national courts. The dispositions of judicial review in Community law rather obstruct effective review. The Court, however, may not decide against the Treaty, hence it is the task of the Member States to alter the provisions in the Treaty.

The message of the Court seems quite clear. It declines to overreach the boundaries of the Treaty, because it is the role of the Member States. Certainly, this also means that the Court does not undertake initiating such direct action for annulment, through which substantial protection of rights can be achieved, without worrying to prove individual concern according to case law. The Court camouflages his resistance to change its position concerning the admissibility of actions for annulment by non-privileged applicants with adequate legal reasoning. Change must be reached through amendment of the Treaty. This passivity contradicts [to some extent] the former practice of the Court pursued in this area of law, when it often contra legem extended its powers under Article $230 \mathrm{EC} .^{18}$

When the Court refers to the amendment of the Treaty, it does not specify which provisions of the Treaty it wishes to modify. It must be considered that according to Arnull, ${ }^{19}$ case law of the Court on individual concern reflects a judicial intention that non-privileged applicants rather attain the annulment of a Community measure via preliminary ruling procedure. Knowing this, it may

${ }^{18}$ Parti Ecologiste Les Verts v. European Parliament C-294/83 [1986] ECR 1339, European Parliament v. Council C-70/88 [1990] ECR I-2041, Commission v. Council C22/70 [1971] ECR 263, Codorniu SA v. Council... op. cit., Extramet Industrie v. Council... op. cit.; see also: Hartley: The Foundations of European Community Law... op. cit. 78-81.; de Burca, G.: EU Law. 2nd ed., Oxford, 1998. 86-95.

${ }^{19}$ Arnull, A.: Private Applicants and the Action for Annulment under A 173 of the EC Treaty, 199532 CML Rev. 41-42, Arnull, A.: Private Applicants and the Action for Annulment after Codorniu, 200138 CML Rev. 7-52. 
not be asserted that under amendment of the Treaty the Court understands solely the modification of Article $230 \mathrm{EC}$, but it is assumable that the judicial will is also aimed at the amendment of Article 234 EC. It must be stated, however, that these procedures serve different purposes and it is necessary that the Court is aware of this when it refers to the amendment of the Treaty.

The European Court of Justice explicitly answered the criticism of its decision in such fashion that in a formalistic sense it leaves no room for objection. On solid grounds it declined the responsibility to establish the complete and effective Community system of judicial protection by judicial means. In its answer it appointed the responsible party and it seems that it made its role clear. Notwithstanding, it should be asked whether the European Court of Justice and the Court of First Instance have done everything by their own means in order to enforce the right to effective judicial protection and to operate a complete and effective system of judicial protection founded by the Treaty.

However, in a substantial point of view, the activity of the European Courts cannot be viewed as adequate. It is true that the courts shall not overreach the scope of formal law, nevertheless, when they interpret and apply the law, they have room for assigning substance to the units of formal law. Article 230 (4) contains the notions of direct and individual concern, which limit the European Courts in finding applications for annulment of Community measures admissible. The European Court of Justice through the interpretation of Community law defined the notion of individual concern in Plaumann. According to this, the applicant is individually concerned if the given Community measure affects him in a way that the applicant can be distinguished from others by reason of certain attributes peculiar to him and by reason of circumstances. The substance of this notion was revealed via case-by-case application, because the notion contains elements, the meanings of which can be explored when they are assigned to the facts in the cases.

When the Plaumann-test is scrutinised, it can be asserted that it is not conclusively determined whom the applicant shall be distinguished from by reason of certain attributes and by reason of circumstances established by the Community measure in question. Nothing orders the European Courts where and how to set up that category in which those individuals belong and from whom the applicant shall differ. The Plaumann-test does not require the courts to distinguish the applicants from its present or potential competitors. It is not set forth that on others than the workers of the same sector, the inhabitants of the same geographical area must be understood. Nothing prevents the European Courts from setting up different closed categories case- 
by-case, on the grounds of which the applicant shall be distinguished from others. Such analysis of the text of the Plaumann-test indicates that the European Courts have and had a wide domain of interpretation when defining the meaning of the notion of individual concern. Which demonstrates that such interpretation is possible when the right to effective judicial protection is enforced in the present system of judicial protection of the Treaty.

The above reading of judicial practices of the European Courts is based on an interpretation according to which the courts first select a closed category that is empty; then they appoint that group of individuals which they think belongs to the closed category by reason of attributes peculiar to them or by reason of circumstances. In the course of such interpretation, however, when the closed category already contains a group of individuals, the membership of the closed category is decided by comparing the individuals included in the closed category with the ones excluded from it. The comparison is also pursued according to the conditions of individual concern in the Plaumanntest, however, selection is restricted, because a reference group is used. Nevertheless, taking into consideration that the members of the reference group are also selected by the courts according to the Plaumann-test, the restriction created by the comparison remains virtual, therefore the courts decide on the question on the basis of a discrepancy from those they see fit. The first interpretation of closed category is based on cases when individual concern could not be determined, because besides the applicant, an indefinable number of individuals would have been individually concerned. ${ }^{20}$ The latter reading is based on cases in which only a small group of individuals had individual concern, and the courts found the applicant not individually concerned by the contested measure, because it could not be distinguished from others within the group. This interpretation is supported by those arguments by the courts, according to which, despite the existence of a small group of individually concerned individuals, the individual concern of the applicant was not wellfounded due to the fact that the number of individuals in the group would have risen by reason of the appearance of new operators in the market. ${ }^{21}$

What kind of new interpretation shall be given, then? The basis of the following approach is that the European Courts shall not interpret the notion of individual concern in a way that anyone would have the right to start an action for annulment, because it is contrary to the Treaty. Hence such

\footnotetext{
${ }^{20}$ Stichting Greenpeace Council v. Commission C-321/95 P [1998] ECR I-1651, Danielsson v. Commission T-219/95 R [1995] ECR II-3051.

${ }^{21}$ Piraiki-Patraiki and Others v. Commission... op. cit., Calpak SpA and Societa Emiliana Lavorazione Frutta SpA v. Commission C-789\&790/79 [1980] ECR 1949, par. 9.
} 
minimum condition should be found that ensures that the requirement of individual concern predominates. If the applicant is able to name his right, the violation of which he supposes, the applicant fulfils the requirement of individual concern. This also purports that the action of annulment would not be open for anybody, because it may be rather difficult to name a violated right. Secondly, this new condition will be sufficient to distinguish the applicant from others in the meaning of Plaumann, if this is still a requirement, because the applicant differs from those, who cannot name such a right. Such adjudication of admissibility would not affect questions of substance, so it does not qualify as prejudicatio. While the opinion of the Advocate General in $U P A^{22}$ suggests another new interpretation of individual concern, the model above will be scrutinised below, together with the approach of the Advocate General. It should be noted that the sole purpose of the above mentioned model is to prove that European Courts have not reached the limits of judge-made law in order to enforce the right to effective judicial protection. European Courts, within the structure of the Treaty, have the power to establish the complete system of effective judicial protection. The conclusion of the Court is incorrect when it asserts that only the Member States are able and obliged to act in order to enforce this right. Because, through interpretation, the European Courts are also able to create a scope for Article 230 (4) EC so that remedy can be given when the rights of individuals are violated.

It must be observed, however, slightly contradicting the above, that the applicant never argued on the basis of individual concern under the regulation in question. The appeal was based solely on the right to effective judicial protection. What the applicant demanded was not an adjustment to the notion of individual concern, but it asked the Court left the wording of the Treaty in order to ensure effective judicial protection. From this point of view, the judgement of the Court seems adequate, because the Court declined to overreach the boundaries of Article 230 (4) EC. If the Court had been asked to reconsider the notion of individual concern in the light of the right to effective judicial protection, the Court would have answered in a different way. In spite of the fact that the applicant's argument evidently lacked certain aspects, the Court should have tackled the question in its entirety.

Does the current system of judicial review comply with fundamental rights-the dictum of the Advocate General? ${ }^{23}$

It is often useful to analyse the opinion of the Advocate General parallel with the judgement of the Court. In this case, however, it is less reasonable,

${ }^{22}$ Opinion of Mr. Advocate General Jacobs on 21 March 2002, [2002] ECR I-6681.

${ }^{23}$ Ibid. 
because Mr. Jacobs is opposed to the opinion of the applicant, the Council, the Commission and the European Court of Justice. This is not contradicted by the fact that the Court under paragraph 43 of its judgement refers in consent to some points of the opinion of the Advocate General, because in this part of its opinion the Advocate General confuted the argument of the applicant, instead of orienting the Court in the direction of the interpretation he suggested.

The opinion of the Advocate General is one of the most comprehensive criticism of the case law of the European Courts concerning Article 230 (4) EC. Mr. Jacobs not only opposes the interpretation of the article, but he is up against the formalist legal arguments presented by the CFI and later by the ECJ. It rejects the solutions proposed in the interventions and refuses to agree with the applicant. The Advocate General points out the weaknesses of the present system of judicial protection and suggests a solution within the framework of the Treaty in order to ensure proper functioning.

The review of Community law by non-privileged applicants is pursued via two means, one through direct action by Article 230 (4) EC, the other through the preliminary ruling procedure under Article 234 EC. The Advocate General concluded that according to the case law of the European Court of Justice, the primary procedure of review of secondary Community law of general application is the preliminary ruling procedure. According to the courts, the preliminary ruling procedure makes the system of judicial protection complete in the framework of the Treaty, because this procedure is open for those who are not able or who were not able to apply for annulment under Article 230 EC. The Advocate General asserted, however, that the system of judicial protection completed by the preliminary ruling procedure is not sufficient to enforce the right to effective judicial protection, because of the peculiarities of the preliminary ruling procedure.

The Advocate General pointed out the following peculiarities. Firstly, he asserted that the preliminary ruling procedure cannot be initiated without a procedure in a national court or tribunal. This may be impossible when no national measure or no damage exists, or the applicant has to initiate a procedure against itself. It costs money and time to reach a court of last resort in the procedure in the national courts, where it is obligatory to request a preliminary ruling. It is not the right of the parties, but the right of the judge in a proceeding in a national court to ask for a preliminary ruling. This also means that the national judge decides which questions to ask and which Community measure it asks to annul. The procedure in the ECJ means further delay and costs. The application of an interim measure is also a problem, because the order on an interim measure requested in different 
Member States depends on the discretion of the national courts and different orders endanger the uniform application of Community law. The interim measure pursuant to Article 230 EC action is valid in all Member States, which ensure uniform application. The Community institution, which ordered the Community measure in question, is not a party in the preliminary ruling procedure contrary to Article $230 \mathrm{EC}$ action. In the action for annulment the courts may deal with all questions related to annulment under Article 234 action, however, the Court is only entitled to answer the judicial questions. The application for action for annulment is published in the Official Journal, meaning that intervention may occur on a wider scale. The two-month deadline in the Article 230 EC procedure ensures that the review of Community law takes place as soon as possible, thus enhancing legal certainty opposed to the preliminary ruling procedure, which may last for years. ${ }^{24}$

The Advocate General may have missed one important momentum when he examined review via Article 234 EC action. Mr. Jacobs asserted that the national court is not entitled to declare a Community measure invalid, and that it may ask for review in case of grounded suspicion of invalidity. The Advocate General nevertheless forgot to deal with the possibility that the national judge does not doubt the validity of the Community measure, even if it has been referred to by the parties during the procedure. The national court is not obliged to ask for preliminary ruling every time suspicion is raised on the validity of a Community measure, because by declaring the Community provision valid, the question of validity does not appear any more in the national court. This momentum may bar out the possibility that the preliminary ruling procedure adequately supplements the action for review under Article $230 \mathrm{EC}$ in order to enforce the right to effective judicial protection in the framework of the Treaty.

The opinion of the Advocate General points out, however, that the limits of this right do not reside exclusively in the peculiarities of the preliminary ruling procedure. Mr. Jacobs submitted that the review of Community measures must be realised in the framework of Article $230 \mathrm{EC}$. He stated that the limits of the vindication of the right of effective judicial protection lies not in the provisions of the Treaty, but in the substance attached by the courts to the provisions of the Treaty. The European Courts must create a new meaning of individual concern in a way that the review of Community law would be possible without violating the right to effective judicial protection. The Advocate General thought that the complete and effective system of judicial protection has not been established within the framework of the Treaty. The Advocate General did not

${ }^{24}$ Ibid. par. 41-49. 
settle for this call, but proposed a new meaning of individual concern. In his view, a person is "individually concerned by a Community measure where, by reason of his particular circumstances, the measure has or is liable to have, a substantial adverse effect on his interests". ${ }^{25}$

It is obvious that Mr. Jacobs in his opinion did not request the transformation of Article 230 (4) EC into an actio popularis, but he wanted to keep the locus standi provided by the article. One may argue for such transformation, nevertheless the opinion focused on the reconstruction of the locus standi, so it will be discussed below.

It must be premised that the centrepiece of the solution suggested by $\mathrm{Mr}$. Jacobs is the dereliction of the main element in Plaumann, the condition that the applicant shall be distinguished from others. The interpretation of individual concern by the courts limited the admissibility of applications to a large extent, because the above mentioned condition of Plaumann allowed the courts to value the applicant's uniqueness as an absolute category. In our view, it is not only uniqueness that establishes individual concern, but individual concern is founded when the applicant can be distinguished from others, together with others. Individual concern is not equal to being the addressee of a measure. The determination of individual concern shall not be refused on grounds that others are similar or they have the potential to be similar to the applicant. The requirement of individual concern must work in a way that it excludes those who are not concerned, but includes those who are not unique but concerned.

Beyond the fact that the Advocate General rejected the requirement of being distinguishable from others, the new interpretation of individual concern raises different problems.

It is difficult to value the notion of interest in legal terms, because there are interests that are outside the scope of law, and there are others that have legal relevance. In my view, an interest gains legal relevance not when it is referred to in a procedure in a court, but when a court in a procedure values it as legally relevant. On this basis it is difficult to specify the interest that shall have legal relevance and get legal protection. When we speak of rights and obligations, however, their relevance and protection by law is obvious.

The notion of adverse effect is also difficult to interpret, because it is not easy to define when an adverse effect would be perceptible. The palpability of adverse effect is a matter of proof in a procedure. When it does not appear in the outside world as a fact, it will be impossible to refer to in a procedure. Adverse effects may appear near at hand as abuse or in the distance as endangering and they may be actual or potential. At which point does it bear

${ }^{25}$ Ibid. par. 56-60. 
relevance? When is it perceptible? The notion of substantial tries to answer to these questions, but its meaning still allows such a wide domain for interpretation that uncertainty around the meaning of individual concern still lingers.

The ambiguities in the interpretation of the approach suggested by Mr. Jacobs are increased further by the fact that by reason of the particular circumstances the measure has or it is liable to have a substantial adverse effect on his interest. This can be interpreted in a way that it corresponds to the notions of certain peculiar attributes and circumstances known from Plaumann, because in some contexts they are the particular circumstances of the applicant. The rights and obligations of the applicant may also belong to the notion of particular circumstances. This notion, which can be interpreted in different ways, still offers a chance for the European Courts to adopt an interpretation of individual concern that does not allow for the enforcement of the right to effective judicial protection.

According to my suggestion for the reduction of uncertainties of interpretation of individual concern, it is sufficient for the applicant to prove individual concern to indicate the right or obligation, the protection of which it asked for in his application. When determining rights and obligations, wellestablished legal categories can be relied upon. Furthermore, it is unnecessary to prove effect and substantiality. Being distinguishable is not a condition, because the indication of rights and obligations does not require the specification of exclusive rights and obligation. An action under Article 230 (4) EC would not be an actio popularis, since the condition of individual concern could not be fulfilled by everybody, since the rights and obligations in Community law are often specific. This means that there are individuals, who have rights or obligations under a specific measure of Community law and there are others who do not. In case of general measures containing rights and obligations for all concerned subjects-at-law, exclusion from judicial protection is not justifiable.

The Advocate General protected his position with different arguments, which support both new interpretations. They suppose that the interpretation of individual concern by the European Courts is unacceptable, and by reaching a new interpretation the European Courts facilitate the establishment of a complete and effective system of judicial protection in the framework of the Treaty. By applying a new interpretation, the denial of justice (déni de justice) can be excluded, and the development of judicial protection could be ensured. If the European Courts applied a new interpretation of individual concern, the controversies in case law could be resolved. Furthermore, the paradox situation implying that the more individuals are affected, the less chance they 
have to prove that they are individually concerned, would cease to exist. This situation is supported by the approach, according to which the more general the interest of the review of a Community measure is, the more the institutions and the Member States shall be obligated to initiate an action for review. It may be submitted, however, that the lack of such action shall not deny access to justice for individuals. According to Mr. Jacobs, this would allow the European Courts to rule more on the merits, and less jurisdiction in matters of admissibility. This does not mean that the Advocate General proposed no examination of admissibility in the proceedings, or that the European Courts should decide on merits when they consider admissibility. Whence, he neither acknowledged that Article 230 (4) EC action was actio popularis, nor argued for jurisdiction against legal principles. Mr. Jacobs stated that a more permissive interpretation of individual concern would fit in the more liberal stance of preceding case law, since the Court often ruled contra legem on the grounds of principles of law (the rule of law) ${ }^{26}$

It must be seen, however, that in these cases the European Court of Justice served its own purpose expanding its jurisdiction. The less strict approach of Article 230 (4) EC action, however, may be contrary to the interest of the European Courts, because a relaxed locus standi means a larger number of cases, and this increase in workload is not compensated by the increase of judicial competence in the Community courts. ${ }^{27} \mathrm{~A}$ dangerous increase of workload may make the functioning of the European judicature impossible.

The Advocate General asserted that the objection against a new interpretation of individual concern cannot be well-grounded. Article 230 EC does not exclude the opportunity for a new interpretation. The political, procedural difficulties of legislation and its length do not justify that a Community measure violating Community law evades review. In addition, the democratic deficit of the legislative procedure emphasises the necessity of review. Finally, the two-month deadline, the condition of direct concern and the future judicial reform make the reference to immense workload as opposed to a relaxed interpretation of individual concern senseless. ${ }^{28}$

One argument against a new interpretation of individual concern was that case law on individual concern was settled.

${ }^{26}$ Ibid. par. 61-67.

${ }^{27}$ Rasmussen, H.: Why is Article 173 EC Interpreted against Private Plaintiffs?, 1980 5 EL Rev. 112-127, 1980; Neuwahl: Article 173 Paragraph 4 EC... op. cit.

${ }^{28}$ Opinion of Mr. Advocate General Jacobs... op. cit. par. $75-81$. 
Whereas Mr. Jacobs stated that case law is not settled regarding all aspects because in several cases the limits of admissibility were indistinct. ${ }^{29}$ The liberal jurisdiction of the national courts and the establishment of the Court of First Instance also supports the departure from case law. According to the Advocate General, the Court applies an interpretation of the principle of effective judicial protection regarding the national courts that it is hard to support the strict interpretation on individual concern applied by the European Courts. ${ }^{30}$

The Advocate General not only expounded his point of view, but he examined the arguments put forward in the procedure by others. The core of the applicant's argument was that in case the application of Article 230 EC action was declined, it would not be granted effective judicial protection. ${ }^{31} \mathrm{Mr}$. Jacobs rejected the argument by stating that the Treaty exactly specifies the locus standi conditions of Article 230 (4) EC action. Furthermore, the European Courts lack the jurisdiction to interpret or annul national laws. An examination of national law by the European Courts concerning the possibility of a review of Community law may be contrary to the former rule. After all, such analysis would establish that admissibility under Article 230 (4) EC would be determined by the laws of the Member States. ${ }^{32}$

The standpoint of the Advocate General differs from the point of view of the applicant only in that it construes the right to effective judicial protection in another context. He asserted that the enforcement of the right resides in the alteration of the interpretation of individual concern. The applicant, however, stated that if any judicial channel is open for his claim then the right is enforced. This argument can be rejected on the grounds that the operation of judicial channels shall not depend on each other. Each one is situated in a specific environment, their functioning serves specific aims and they require particular conditions when initiated. The individual seeking judicial protection shall choose the one that is more effective.

The Advocate General rejects the submission of the Council and the Commission on the functioning of a complete system of judicial protection in the Community, and states that Article 234 EC action would not be a right even if national rules were changed, because a court-case cannot be created by

${ }^{29}$ Ibid. par. $82-85$.

${ }^{30}$ Ibid. 22, par. 89-99, see Johnston v. Chief Constable of the URC C-228/84 [1986] ECR 1651, Brasserie du Pecheur SA V. Germany and $R$ v. Secretary of State of Transport, ex parte Factortame Ltd and Others C-46/93 and C-48/93 [1996] ECR I-1029, Verholen and Others v. Sociale Versekeringsbank C-87-89/90 [1991] ECR I-3757.

${ }^{31}$ Opinion of Mr. Advocate General Jacobs... op. cit. par. 34.

${ }^{32}$ Ibid. par. 37. 
amending the rules of procedure. On the other hand, if a review through preliminary ruling was made more accessible, it would not help the problem of Article 230 (4) EC action. ${ }^{33}$

When analysing the decisions of the European Courts it must be taken into consideration that they are the units of a process. They represent a standpoint of the law, at the same time they open up new chances for further development in the law. That is why, it must be examined which parts of the judgement define the future evolution of law.

In its judgement the Court rejected its further obligation concerning the enforcement of the right to effective judicial protection on formalist grounds. It positioned this obligation on the Member States. Now, there is no amendment of the Treaty in prospect that would directly concern Article 230 (4) EC. The judicial reform in the Treaty of Nice ${ }^{34}$ may indirectly have such effect, that the European Courts would ease the conditions of admissibility. This statement is based on the assumption that the cause of judicial conservatism shown during the interpretation of the conditions of admissibility is that with strict conditions of admissibility the workload of European judicature can be lessened. After the Treaty of Nice entering into force, if not the number of applications, but the workload on the European Courts will decrease by the distribution of case. Therefore, it would be possible to declare more applications admissible. The decrease of workload can be influenced by the number of judicial panels, their competence and by the number of final judgements in first instance.

\section{The CFI departs from settled case law: the Jégo-Quéré judgement}

In this procedure the case law on the individual concern of non-privileged applicants had a particular turn. The events just heightened the obtuseness with the activity of the European Courts in this field. The Advocate General presented his opinion on the UPA case on 22 March 2002. The Court of First Instance decided in Jégo-Quéré on the 5th of May. The European Court of Justice brought its judgement on 25 July 2002. The succession of events requires us to assert that in spite of new elements in case law, the legal situation has not changed. The analysis of the judgement in Jégo-Quéré shall not be ignored, because the decision contains such new judicial approach that, in our view, must be followed and the examination of the judgement can point out the weaknesses of the new approach.

${ }^{33}$ Ibid. par. 56-58.

${ }^{34}$ Treaty of Nice, OJ C 80, 10/03/2001. 1-87. 
The applicant French enterprise asked for the annulment of certain provisions of Regulation 1162/2001 EC Er $^{35}$ from the Court of First Instance under Article 230 (4) EC. The Regulation applying to certain fishing vessels and its provisions set the minimum mesh sizes used by the vessels. The Commission raised an objection of inadmissibility and asked the court to reject the application.

The argument of the applicant can be divided into two. First, it deals with the nature of the given Community measure and with its being of individual concern to it. Second, the core of its argument concerns the enforcement of the right to effective judicial protection. It asserted that the Regulation is rather a bundle of decisions, than a measure of general application. The Regulation concerned it individually, because it was distinguishable from others on the basis that it was the only French undertaking fishing in the Celtic Sea. In the course of legislation the Commission was obliged to observe the fact that the applicant fishes for fish that are smaller than hake, therefore, the increase of mesh sizes deprives it from its catch.

The applicant concluded that besides Article 230 EC action, no other means of judicial protection were available and asked the court to adopt a relaxed interpretation of Article $230 \mathrm{EC}$ in the light of Article 6 of the ECHR.

The argument of the Commission also followed two directions. First, it denied the individual concern of the applicant. Furthermore, it stated that the applicant was not denied of other means of judicial protection. When it examined individual concern, it analysed first the nature of the measure in question and asserted that according to case law, even tough it was a measure of general application, the applicant may be of individual concern to it. ${ }^{36}$

According to the Commission, however, individual concern was not proven in this case, because the scope of the Regulation was set by objective criteria. The Regulation applies to all fishing vessels equally within its scope. There was no higher rule of law that obliged the Commission to take account of the situation of the applicant in the course of legislation. The Commission stated that alternative means of judicial protection are Articles 235 and 288 (2) EC, which regulate the action for non-contractual liability of the Community.

\footnotetext{
${ }^{35}$ Commission Regulation (EC) No. 1162/2001 of 14 June 2001 establishing measures for the recovery of the stock of hake in ICES sub-areas III, IV, V, VI and VII and ICES divisions VIII $a, b, d$, e and associated conditions for the control of activities of fishing vessels, OJ L 159, 15/06/2001. 4-9.

${ }^{36}$ Codorniu SA v. Council... op. cit., Extramet Industrie v. Council... op. cit.; Campo Ebro and Others v. Council T-472/93 [1995] ECR II-421, ACAV and Others v. Council T138/98 [2000] ECR II-341.
} 
The Court of First Instance, lead by the president of the court, proceeded in an extended composition chamber and asserted that the Community measure under scrutiny is of general application, because it applies to undefined classes of persons and to objectively determined situations. According to settled case law, ${ }^{37}$ measures of general application can be of individual and direct concern to some economic operators. The condition of direct concern is fulfilled because the application of the Regulation does not depend on the discretion of a third person. The examination of individual concern was done by applying the general concept of Plaumann, and by applying case law crystallised categories, in which individual concern was always established. The court did not accept individual concern as proven by the applicant under the notion in Plaumann, because the Regulation affects the applicant as a fishing undertaking, and as such, it cannot be distinguished from other fishing undertakings. In case law, individual concern was established many times, and the legislator was obligated to take into account the applicant when making the Community measure, however, this time it was not the case. Under Community law, the applicant had no procedural rights or guarantees, so these specific cases do not establish individual concern of the applicant. The court asserted that the applicant was not in a special position, nor had special rights in order to be distinguishable from others. ${ }^{38}$

However, the argument of the Court of First Instance took a turn. The court ascertained that the Community is based on the rule of law and that Community law established a complete system of legal remedies in order to facilitate a system of review of Community law. ${ }^{39}$ The obligation of effective judicial protection is based on the constitutional traditions common to the Member States and on Articles 6 and 13 of the ECHR. Under Article 47 of the Charter of Fundamental Rights of the European Union proclaimed at Nice on 7 December $2000,{ }^{40}$ the European Courts shall give remedy to the party whose rights and freedoms are guaranteed under the law of the Union. Fully aware of this obligation, the Court of First Instance stated that the inadmissibility of an action for annulment, where a non-privileged applicant

${ }^{37}$ Piraiki-Patraiki and Others v. Commission... op. cit.; Sofrimport v. Commission... op. cit.; Antillean Rice Mills v. Commission... op. cit.; Rica Foods v. Commission... op. cit.; Sociedade Agricola dos Arinhos and Others v. Commission... op. cit.; Extramet Industrie v. Council... op. cit.; Codorniu SA v. Council.. op. cit.; Emesa Sugar v. Council T-43/98 [2001] ECR II-3519.

${ }^{38}$ Ibid.

${ }^{39}$ Parti Ecologiste Les Verts v. European Parliament... op. cit.

${ }^{40}$ OJ 2000 C 364, 1. 
requests the annulment of a measure of general application, would mean that the applicant shall be deprived of the right to effective judicial protection.

According to the court, the review via preliminary ruling is not an adequate means of judicial protection, because the enforcement of the right to effective judicial protection shall not force an individual to violate the law. The action for non-contractual liability of the Community is not an alternative judicial remedy, because in this procedure the annulment of Community law does not take place. The question of admissibility and the questions on the merits are often examined together, as it is excluded in Article $230 \mathrm{EC}$ action. In this procedure, the analysis of lawfulness does not reach the same level as in the action for annulment.

The Court of First Instance asserted that under the ECHR and the Charter of Fundamental Rights of the European Union, the Community system of remedies cannot provide effective judicial protection in a case, when such Community measure of general application is under review, directly affecting the legal position of the applicant. This situation, however, does not entitle the Community judicature to depart from the provisions of the Treaty. The only possible solution is the new, relaxed interpretation of individual concern within the framework of Article 230 EC.

The Court of First Instance gave the following interpretation to the notion of individual concern. "In order to ensure effective judicial protection for individuals, a natural or legal person is to be regarded as individually concerned by a Community measure of general application that concerns him directly, if the measure in question affects his legal position, in a manner which is both definite and immediate ${ }^{41}$ by restricting his rights or by imposing obligations on him. The number and position of other persons, who are likewise affected by the measure, or who may be so, are of no relevance to that regard." 42

By applying the new test, the Court found the applicant individually concerned, because the Regulation imposed obligations on Jégo-Quéré. The application, therefore, was found admissible.

The approach of the Court of First Instance is radical, since it recalls those times, when the Court declared actions for annulment of regulations lodged by non-privileged applicants admissible. ${ }^{43}$ This is a judicial approach, which had been demanded by the critics and with which, in our view, the European Courts had owed for a long time, if they acknowledge that Community law is based on the rule of law. The new judicial attitude is welcomed without

${ }^{41}$ Certaine et actuelle, unzweifelhaft und gegenwartig.

${ }^{42}$ Par. 51, in: Jégo-Quéré et Cie SA v. Commission... op. cit.

${ }^{43}$ Extramet Industrie v. Council... op. cit.; Codorniu SA v. Council.. op. cit. 
reservation, if it is expressed in the decision on merits. This means that the new interpretation of individual concern shall establish such locus standi, which creates the conditions of effective judicial protection within the framework of the Treaty.

The argument of the court in one section runs parallel with the argument applied in UPA. The starting point is the rule of law and the obligation derived from it, so that a complete and effective Community system of remedies must be established at the disposal of Community subjects-at-law. The court sees the effective judicial protection not only as an obligation, but as a right, which can be deduced from the common constitutional traditions of the Member States, from the ECHR and from the Charter of Fundamental Rights of the European Union. In spite of the fact that reference to the latter is questionable due to its legal nature, it is acceptable on similar grounds as the reference to the ECHR. The Court of First Instance sees in that way that the present system of judicial remedies is not complete and effective with respect to the right and the obligation mentioned above.

At this point the arguments depart. While in UPA the obligation of the Member States comes into focus, in this case the court examines the obligation of the European Courts regarding the complete and effective system of judicial protection.

According to the court, in order to enforce the right to effective judicial protection, a new interpretation of individual concern is required. The court creates the new notion of individual concern from the following elements: measure of general application that concerns the legal position of the applicant directly; definitely and immediately, by restricting his rights or by imposing obligations on him, and the number of persons affected is not relevant.

According to the judgement of the Court of First Instance, the court wants to apply the new conditions of individual concern only in actions for annulment of measures of general application, i.e. regulations. The text of the judgement refers to measures of general application, which means that in case of a decision addressed to another person or in case of a decision in the form of regulation, the applicant in an action for annulment must prove individual concern by applying the interpretation in Plaumann. It appears that the Court of First Instance does not intend to treat the right to review of non-privileged applicants equally in respect of regulations and other Community measures mentioned in the Treaty. If the wording of the new interpretation was intended, it must be stated that this distinction cannot be justified on the grounds of general or individual nature of Community measures. The obligation to establish a complete and effective system of remedies requires the court to 
extend the new interpretation of individual concern to decisions addressed to another person and to decisions in the form of regulation.

In connection with the nature of the Community measures under review it requires an explanation, why it was important in the argument of the parties that the Community measure in question was of general application or it was a bundle of decisions? Arnull stated that in UPA a similar argument was made by the Court, when it stated that the applicant would be of individual concern to the regulation in question, because the regulation had the nature of a decision in that regard. ${ }^{44}$ After Codorniu this argument is incomprehensive, however, it can be asserted that the examination of the nature of the Community measure is a common element in the arguments of judgements of the European Courts. ${ }^{45}$ In our view, this is only applied to create a complete line of argument, because the courts every time assert that the review of measures of general application is possible when individual concern of non-privileged applicants is proven. The complete line of argument is needed, because case law somewhat deflects from the wording of the Treaty, according to which, the action for annulment of regulation is the right of the Institutions, the ECB and the Member States. The courts shall reinforce the legal basis of the review case-by-case, which is contrary to the Treaty, in order to avoid the questioning of jurisdiction that is in compliance with the Treaty.

The court inserted the requirement of direct concern into the new concept of individual concern. This suggests that the court ensures that both conditions in Article 230 (4) EC are fulfilled by the applicant. ${ }^{46}$

According to the judgement in Jégo-Quéré, in order to establish individual concern the applicant must prove that the Community measure in question affects his legal position in a manner which is both definite and immediate, so it restricts his rights or imposes obligation on him. If the notions of restriction of rights and imposition of obligations imply the meaning of the notion of definite and immediate effect on the legal position, it is questionable whether it is necessary to include both the result of interpretation and the notion under interpretation in the new concept of individual concern. If the expressions can substitute each other, in our view, it is sufficient to indicate only the restrictions of rights and the imposition of obligations, because these notions restrict the European Courts in their discretion when deciding

${ }^{44}$ Arnull, A.: Editorial Comments, 200227 EL Rev.

${ }^{45}$ Union de Pequenos Agricultores, Jégo-Quéré et Cie SA v. Commission... op. cit., Federacion de Cofraidas de Pescadores de Guipuzcoa and Others v. Council.

${ }^{46}$ Par. 26, 43, 47, in: Jégo-Quéré et Cie SA v. Commission... op. cit. 
on admissibility. Legal certainty requires such legal provisions that make legal actions predictable.

When the expressions are not substitutable, it is difficult to define the notion of effect on legal position. Although, the application of the categories of "definite" and "immediate" can narrow the domain of interpretation defined by "restriction of rights and imposition of obligations". Case-by-case the content of the new interpretation of individual concern could be defined, if the premises applied in the enforcement of the right to effective judicial protection are derived from the rule of law.

The Court of First Instance undoubtedly indicated that it wanted to relinquish the application of the method in Plaumann, which required the courts to distinguish the applicant from all others. It undertook to concentrate solely on the position of the applicant irrespective of others surrounding him. This is the only part of the new conditions of individual concern that is worth welcoming, because the above mentioned critical remarks show the shortcomings of the new method of examining individual concern suggested by the court. This means that in spite of the fact that the court stopped applying the method of closed category, it rejected to restrict its operations within the frame of well-definable notions.

The purpose of examining uncertainty is not to prove that a concept of individual concern that has absolute meaning is necessary, rather it is to point out the advantages of the method suggested by us against the suggestions of the Advocate General and the court. We think that the new concept of individual concern should bear the highest degree of certainty without the exclusion of individuals from the review of Community measures.

At this point, it is necessary to compare the core solutions of the three suggested methods in order to choose the most adequate. The Advocate General gave the widest domain to individual concern, when he required the proof of substantial adverse effect on the applicant's interest. Our suggestion of the indication of rights and obligations defines a narrower scope, because rights and obligations represent a narrower domain than interests. The restriction of rights and imposition of obligations suggested by the Court of First Instance is the narrowest interpretation, because that requires activated rights and obligations. Parallel to this, it can be stated that by narrowing the domain of interpretation the definability of the concepts increased. While the notion of interest applied in the first solution is definable with difficulty, the content of rights and obligations, restriction of rights and imposition of obligation can be determined easier. In our view, the limitation of the concept to restriction of rights and imposition of obligations is unjustified, 
because remedies shall not be provided only for those whose right has been restricted or who has been obligated. Rather, those shall also have a share in judicial protection, whose right would be restricted or whom obligation would be imposed upon. The Community measure under review does not always cause immediate violation of law, but it often carries this potential. ${ }^{47}$ If a Community measure violates Community law, it does not mean that it also violates the rights of an individual, because the grounds of illegality in Article 230 EC only means the violation of Community law and not the rights of an individual. That is why it is necessary to establish such concept of individual concern that provides that individuals, whose rights can potentially be violated by a Community measure, may ask for the review of that Community measure. It is not justified to leave the action for review of the Community measure in case of indefinite and not immediate violation of law to privileged applicants, because without being affected they will not perceive that the Community measure does indeed violate Community law. The affected individuals have no such mechanism at their disposal through which they could enforce any privileged applicant to launch an action for annulment. The most effective way to enforce the right to effective judicial protection is to ensure that the affected persons have the right to initiate such proceedings.

In the course of analysis other factors outside the scope of law must be considered. The publication of the opinion of the Advocate General a few weeks ago must have had a great effect on the development of the judicial approach. In spite of the fact that the applied interpretations on individual concern differed, the starting point of their approach was the same: the need for a new interpretation in order to establish effective judicial protection in the Community.

In this case a regulation of the Common Fisheries Policy was under review. This sector is in deep crisis, because the amount of fish in the seas has decreased significantly as a consequence of excessive fishing activity. The reforms suggested and implemented by the Commission sensitively affect the undertakings in the sector, because their means of earning a living is in danger. The reception of the measures of the Commission often degenerates into violent acts by these people. Every week, during protests against the new rules, the fresh catch is dumped in front of the buildings of fishing authorities. When courts apply the law, they shall not leave the social circumstances [behind the law] out of consideration.

\footnotetext{
${ }^{47}$ Stichting Greenpeace Council v. Commission... op. cit., Danielsson v. Commission... op. cit.
} 


\section{Closing remarks}

The new radical concepts emerging in case law and in the opinion of the Advocate General have grounds to call the constructive judicial activity of the Court, which has defined Community law in its basis, on account. It is questionable that the European Court of Justice rejects the two reform concepts on purely formalistic legal grounds. That Court, which have created the missing elements of the Community system of judicial protection of individuals in its case law, cannot back out from the obligation of further perfection of the Community system of remedies.

The significance of Jégo-Quéré is that the Court of First Instance rejected the condition of being distinguishable from others, as the core element of the concept of individual concern. According to this, the applicant has to concentrate on his position in the proceeding. In our view, however, under the criteria set in the case, the group of individuals, who may qualify as individually concerned, is set narrow without reason. Only in case of real violation of law, i.e. restriction of rights or imposition of obligations, would their actions be admissible. Judicial interpretation would preclude individuals whose rights are not violated directly at the effective date of the Community measure and allow action for them later, when the result aimed by the Community measure ensues. Nobody shall be excluded from the review of a Community measure violating Community law, if the right of that person would be violated by the later effect of the unlawful measure.

In the light of the UPA judgement it must be stated that according to case law individual concern must be interpreted as in Plaumann. ${ }^{48}$ According to the argument of the applicant in UPA, it had locus standi under Article $230 \mathrm{EC}$ action because Article 234 EC action was not open for his application, therefore, in order to enforce the right to effective judicial protection, the direct action for review shall stand for its disposal. The Court rejected the argument by stating that it had no jurisdiction to examine national laws whether they serve Article 234 EC action appropriately. The Court of First Instance rejected the same argument on the same basis in case SLIM Sicilia only a month after the judgement in Jégo-Quéré. ${ }^{49}$ Three months after the decision in Jégo-Quéré, the President of the CFI repeated the UPA judgement stating that the lack of

\footnotetext{
${ }^{48}$ See: Arnull's comment: Plus Ça Change.., Arnull: Editorial Comments... op. cit.

${ }^{49}$ SLIM Sicilia v. Commission T-105/01 [2002] ECR II-2697, par. 55, Order of 6 June 2002.
} 
other means of judicial protection does not require the court to depart from the conditions of admissibility set in Article 230 (4) EC. ${ }^{50}$

In view of the functioning of the European Courts, the Jégo-Quéré judgement is not the result of a communication failure. The European Court of Justice does not want to alter the present set of conditions. It must be seen, however, that the judgement in Jégo-Quéré is the part of Community law, and it has not been reversed yet by the European Court of Justice in an appeal procedure. The judgement of the Court of First Instance can be relied upon and it will be relied upon. Furthermore, the proceedings in Jégo-Quéré are still underway, only the question of admissibility was decided. The decision on merits will follow the possible appeal, the opinion of the Advocate General will come later, and finally, the judgement of the European Court of Justice will hopefully clarify the situation. The process is not over yet and it is still possible that the interpretation of individual concern will change in the forthcoming months. ${ }^{51}$

${ }^{50}$ Order of the President of the CFI, VVG International and Others $v$. Commission T155/02 R of 8 August 2002, par. 39.

${ }^{51}$ The comments of Allan F. Tatham and Ernõ Várnay are gratefully acknowledged. 